\title{
Pengembangan Kualitas Layanan Jasa Bank PD. BPR Sarimadu Bangkinang
}

\author{
ARMAN \\ Sekolah Tinggi Ilmu Ekonomi Bangkinang \\ Jl. Dr. A Rahman Saleh, Bangkinang, Kabupaten Kampar, No. 54, Riau 28463 \\ E-mail : arman@lecturer.stie.bangkinang.ac.id
}

\begin{abstract}
PD Bank. BPR Sarimadu Bangkinang is one of the people's credit banks that is growing rapidly. Tight competition makes this regional company think about how to win the competition and win customers. One variable that can be developed is the variable quality of service. Where through the survey research approach to customers as many as 100 customers and analyzed descriptively. The research results obtained that in order to develop the quality of service for this company, what needs to be done is to develop the physical evidence of the bank. Appearance of physical facilities, equipment, personnel and communication materials; development of reliability. The ability to carry out promised, reliable and accurate services; development of bank responsiveness. Willingness to help customers and provide prompt service; development of customer guarantees. Credibility, trust, honesty of service providers; the development of empathy for matters that are easily approachable, communication listening to customers and keeping them informed in understandable language; understanding customers, making efforts to recognize customers and their needs and developing easy-to-use products. Products are easy to use with the availability of information on the web, then the ease of transaction.
\end{abstract}

Keywords: Service Quality, PD Bank. BPR Sarimadu

Bank Perkreditan Rakyat yang selanjutnya disebut BPR yaitu bank yang melaksanakan kegiatan usaha secara konvensional yang dalam kegiatannya tidak memberikan jasa dalam lalu lintas pembayaran sebagaimana dimaksud dalam Peraturan Otoritas Jasa Keuangan Nomor 20/Pojk.03/2014 Tentang Bank Perkreditan Rakyat.

Bank PD. BPR Sarimadu pada awalnya merupakan salah satu Badan Kredit Kecamatan (BKK) dari 6 (enam) BKK yang didirikan dengan Surat Keputusan Gubernur Nomor : 609/IX/1986, Instruksi untuk mendirikan Badan Kredit Kecamatan (BKK) pada setiap Kabupaten di Propinsi Riau dan Surat Keputusan Bupati Kampar Nomor : 41/V/Perek/1987, tentang Badan Kredit Kecamatan (BKK) di Kabupaten Kampar yang ditempatkan di Ujungbatu. Modal Awal BKK Ujungbatu berasal dari pinjaman kepada BPD Riau (Bank Riau) sebesar Rp 10.000.000,- (sepuluh juta rupiah) yang dijamin oleh Pemerintah Daerah Kabupaten Kampar.

Pada mulanya BKK Ujungbatu dikelola oleh 3 orang yang berkantor di Kantor Camat Tandun dan diresmikan oleh Bupati Kampar Bapak H. Saleh Djasit, SH pada tanggal 27 Juni 1987. Melaui deregulasi perbankan tanggal 28 Oktober 1988 (Pakto '88) dengan SK Presiden Nomor : 38 Tahun 1988 dan SK Menteri Keuangan RI Nomor : 1064/MK.00/1988 dan Nomor : 279/KMK.01/1988, BKK Ujungbatu dipersiapkan untuk menjadi Bank Perkreditan Rakyat (BPR). Gubernur Propinsi Riau dengan Surat Keputusannya Nomor : 539/PSD/86.18 tanggal 18 Desember 1988 menginstruksikan kepada Bupati untuk mempersiapkan pendirian Bank Perkreditan Rakyat (BPR) dalam wilayah masing-masing Kabupaten. Selanjutnya dengan persetujuan DPRD Kabupaten Kampar, Pemda Kabupaten Kampar membentuk BPR ini menjadi 
Perusahaan Daerah (PD) melalui Peraturan Daerah (Perda) Kabupaten Kampar Nomor : 03 Tahun 1989. Atas persetujuan Bank Indonesia, Menteri Keuangan memberikan izin operasional melalui SK Nomor : Kep.067/KM.13/92 tanggal 16 Maret 1992 tentang Pemberian izin usaha PD. Bank Perkreditan Rakyat Ujungbatu. Dengan demikian, BKK Ujungbatu resmi beralih status menjadi Bank PD. BPR Ujungbatu. Kemudian dengan Perda Kabupaten Kampar Nomor : 9 Tahun 2003, Nama Bank PD.BPR Ujungbatu berubah nama menjadi Bank PD. BPR Sarimadu.

Sesuai dengan perkembangannya serta sejalan dengan pemberlakuan Undang Undang Nomor 53 Tahun 1999 tentang Pembentukan Kabupaten Pelalawan, Kabupaten Rokan Hulu, Kabupaten Rokan Hilir, Kabupaten Siak, Kabupaten Natuna, Kabupaten Karimun, Kabupaten Kuantan Singingi dan Kota Batam, maka Kantor Pusat Bank Sarimadu yang semula berada di Ujungbatu Kabupaten Rokan Hulu, Pindah ke Bangkinang ibu kota Kabupaten Kampar, sedangkan Kantor Pusat di Ujungbatu berubah status menjadi Kantor Cabang Ujungbatu.

Kepemilikan saham Bank PD. BPR Sarimadu pada awalnya berasal dari Pemda Kabupaten Kampar dan BPD Riau (Bank Riau Kepri) dengan perbandingan kepemilikan saham $85 \%$ Kabupaten Kampar dan 15\% Bank Riau. Seiring dengan perubahan modal dasar, berdasarkan Rapat Umum Pemegang Saham tahun 2000 Bank Riau memberikan kesempatan kepada Pemda Kampar untuk secara bertahap memiliki seluruh modal Bank PD. BPR Sarimadu. Dengan ditetapkannya Perda Nomor : 09 tahun 2003, maka kepemilikan modal Bank PD. BPR Sarimadu selanjutnya dimiliki seluruhnya oleh Pemda Kabupaten Kampar.

Bank PD. BPR Sarimadu merupakan salah satu Badan Usaha Milik Daerah (BUMD) Kabupaten Kampar yang bergerak dibidang Lembaga Keuangan Perbankan (Bank Perkreditan Rakyat) dengan izin operasional dari Menteri
Keuangan Republik Indonesia Nomor : Kep.067/KM.13/92 tanggal 16 Maret 1992 tentang Pemberian izin usaha PD. Bank Perkreditan Rakyat Ujungbatu.

Persaingan yang ketat membuat perusahaan daerah ini memikirkan bagaimana memenangkan persaingan dan merebut hati nasabah. Salah satu variabel yang dapat dikembangkan adalah variabel kualitas layanaan.

Kualitas pelayanan merupakan konsep penting untuk menarik minat pelanggan dalam pemasaran dan manejemen operasi. Sasser et.al dan Lehtinen dalam Angus Duff dan Hair (2008:306) mengidentifikasi bahwa kualitas pelayanan merupakan sebagai perbandingan mengenai apa yang diharapkan konsumen dengan apa yang didapat oleh konsumen. Menurut Gronroos dalam Angus Duff dan Hair (2008:306) mendefinisikan bahwa kualitas pelayanan merupakan keluaran sebagai proses evaluasi, dimana membandingkan harapan dengan pelayanan yang diterima.

Pentingnya kualitas pelayanan memiliki kontribusi terhadap pengembangan menjalin hubungan yang baik dari yang tidak diketahui oleh perusahaan sehingga dapat diidentifikasi mengenai kelemahan- kelemahannya (Holmund and Koc;Tumbull and Gibbsdalam Angus Duff, 2008).

Kualitas pelayanan pada awalnya dikemukakan oleh (Parasuraman dalam Santoso (2012: 23) yang dikenal dengan sebutan "SERVQUAL". Konsep SERVQUAL pada mulanya dipakai pada industri-industri atau perusahaan untuk mengidentifikasi seberapa besar tingkat pemberian pelayanan terhadap karyawan maupun pelanggan. Konsep SERVQUAL dikenal dengan lima dimensi sebagaiberikut: Tangible; Reliability; Responsiveness; Assurance; Empathy.

Beberapa pendapat tersebut di atas, maka dapat disimpulkan bahwa kualitas pelayanan adalah sebagai perbandingan mengenai apa yang diharapkan konsumen 
dengan apa yang didapat oleh konsumen, dengan indicator dikenal dengan lima dimensi sebagaiberikut: Tangible; Reliability; Responsiveness; Assurance; Empathy.

Kualitas pelayanan merupakan konsep penting untuk menarik minat pelanggan dalam pemasaran dan manejemen operasi.Sasser et.al dan Lehtinen dalam Angus Duff dan Hair (2008:306) mengidentifikasi bahwa kualitas pelayanan merupakan sebagai perbandingan mengenai apa yang diharapkan konsumen dengan apa yang didapat oleh konsumen. Sedangkan menurut Gronroos dalam Angus Duff dan Hair (2008:306) mendefinisikan bahwa kualitas pelayanan merupakan keluaran sebagai proses evaluasi, dimana membandingkan harapan dengan pelayanan yang diterima.

Pentingnya kualitas pelayanan
memiliki $\quad$ kontribusi pengembangan menjalin hubungan yang baik dari yang tidak diketahui oleh perusahaan sehingga dapat diidentifikasi mengenai kelemahan- kelemahannya (Holmund and Koc ;Tumbull and Gibbsdalam Angus Duff, 2008: 306). Kualitas pelayanan pada awalnya dikemukakan oleh (Parasuraman dalam Santoso (2012: 23) yang dikenal dengan sebutan "SERVQUAL". Konsep SERVQUAL pada mulanya dipakai pada industri-industri atau perusahaan untuk mengidentifikasi seberapa besar tingkat pemberian pelayanan terhadap karyawan maupun pelanggan. Konsep SERVQUAL dikenal dengan lima dimensi sebagai berikut: Tangible; fasilitas fisik, peralatan dan kelengkapan karyawan; Reliability, kehandalan yang dimiliki oleh pihak perusahaan terhadap pelayanan; Responsiveness; kecepatan dalam menanggapi berbagai hal yang timbul dalam pelayanan; Assurance; jaminan perusahaan atau karyawan untuk membangun kepercayaan; Empathy, perhatian dari individu terhadap pelanggan.
Dalam bidang perbankan, konsep pengukuran kualitas pelayanan yang menggunakan metode SERVQUAL terdapat beberapa perubahan. Hal ini dikarenakan adanya perbedaan karakteristik antara industri manufaktur dengan industri perbankan, dimana perbedaan tersebut diantaranya bahwa industri manufaktur lebih memfokuskan terhadap faktor kualitas dan kuantitas produksi untuk mencapai tingkat kepuasan pelanggan, sedangkan untuk industri perbankan lebih memfokuskan ke dalam pelayanan jasa dalam memuaskan pelanggannya.

Beberapa penelitian yang berkontribusi terhadap perkembangan konsep SERVQUAL di antaranya Blanchard and Galloway Newman yang telah meneliti beberapa perbankan di United Kingdom, kedua peneliti tersebut menyatakan bahwa konsep SERVQUAL yang diterapkan pada bank kurang mampu mempresentasikan secara keseluruhan mengenai tingkat pelayanan sehingga hal ini diperlukan adanya pengembangan dari model SERVQUAL. Peneliti selanjutnya dilakukan oleh Cronin dan Taylor yang mengkombinasikan konsep SERVQUAL dengan konsep SERPERF. Hasil penelitiannya membuktikan bahwa kombinasi model SERVQUAL dan SERPERF dapat membuktikan secara empiris untuk mengukur kualitas pelayanan pada industri bank. Selanjutnya alat untuk mengukur tingkat kualitas pelayanan pada sebuah bank yang dikenal dengan BANKSERV yang terdiri atas dimensi: Staff conduct; Credibility; Communication; Acces to teller service.

Johnston dalam Tatang (2014: 41) mengkombinasikan item SERVQUAL yang diperoleh dari konsep kerangka bauran pemasaran, sehingga konsep ini berkembang dengan nama Bank Service Quality (BSQ) yang terdiri dari enam dimensi yaitu: Effectiveness and assurance;Access;Price;Tangible;Service portfolio, and;Reliability. 
Othman and Owen dalam Tatang (2014: 42) mereview konsep original dari item SERVQUAL ke dalam konsep perbankan islam. Hasil penelitian tersebut telah berhasil mengembangkan konsep SERVQUAL ke dalam konsep pengukuran kualitas pelayanan perbankan dengan nama CARTER. Adapun konsep CARTER sebagai berikut: Compliance with Islamic law;Assurance;Reliability;Tangibles;Emph aty; and Responsiveness.

Tjiptono dan Chandra (2005:121) dalam penelitiannya menggunakan konsep kualitas pelayanan dalam mengukur tingkat kualitas perbankan dari konsep BSQ (Bank Service Quality) yang mengacu pada Groonross (2007) dan (Bahia and Nantel, 2000). Dimensi kualitas yang dikemukakan oleh Gronross dan Bahia and Nantel merupakan kriteria untuk mengukur kualitas pelayanan pada sebuah bank yang dikenal dengan BSQ (Bank Service Quality). Keenam dimensi karakteristik kualitas pelayanan menurut Gronross (2007) dan Bahia and Nantel (2000) adalah : Professionalism and skill. Pelanggan mendapati bahwa penyedia jasa, karyawan, sistem operasional, dan sumber daya fisik, memiliki pengetahuan dan keterampilan yang dibutuhkan untuk memecahkan masalahnya secara professional (outcomerelated criteria); Attitudes and Behavior. Pelanggan merasa bahwa karyawan jasa (customer contact personnel) menaruh perhatian besar pada pelanggan dan berusaha membantu memecahkan masalahnya secara spontan dan ramah (process-related criteria); Accessibility and Flexibility. Pelanggan merasa bahwa penyedia jasa, lokasi, jam operasi, karyawan, dan sistem operasionalnya, dirancang dan dioperasikan sedemikian rupa sehingga pelanggan dapat mengakses jasa tersebut dengan mudah. Selain itu, juga dirancang dengan maksud agar dapat menyesuaikan permintaan dan keinginan pelanggan secara luwes (process-related criteria); Reliability and Trustworthiness. Pelanggan merasa bahwa apa pun yang terjadi atau telah disepakati, bisa mengandalkan penyedia jasa beserta karyawan dan sistemnya dalam memenuhi janji dan melakukan segala sesuatu dengan mengutamakan kepentingan pelanggan (process-related criteria); Recovery. Pelanggan menyadari bahwa bila terjadi kesalahan atau sesuatu yang tidak diharapkan dan tidak dapat diprediksi, maka penyedia jasa akan segera mengambil tindakan untuk mengendalikan situasi dan mencari solusi yang tepat (process-related criteria); Reputation and Credibility. Pelanggan meyakini bahwa operasi dari penyedia jasa dapat dipercaya dan memberikan nilai/tambahan yang sepadan dengan biaya yang dikeluarkan (image-related criteria).

Penelitian yang dilakukan oleh Angus Duff dan Hair (2008: 210) yang telah berhasil mengkombinasikan dari seluruh dimensi dan ukuran di atas ke dalam penyempurnaan dalam metode pengukuran kualitas pelayanan pada sebuah Bank dengan sebutan CBSQ (Chiness Banking Service Quality) yang terdiri dari : Reliability; Empathy; Facilities and equipment; Human capital; Acces; Technology;Communication.

Lovelock (2011: 155) kualitas pelayanan memiliki 10 dimensi: berwujud (tangibles); kehandalan (reliability); responsiveness; kredibilitas; keamanan; kompetensi; sopan santun; akses; komunikasi; memahami pelanggan. Tjiptono (2012: 170-172) kualitas pelayanan memiliki 8 dimensi: kinerja (performance); fitur (features); reliabilitas (reliability); kesesuaian dengan spesifikasi (conformance to specifications); data tahan (durability); service ability; estetika; persepsi kualitas (perceived quality)

Farnaz (2012: 444) kualitas pelayanan jasa perbankan dengan 6 dimensi sebagai berikut: eficient and realibel service (pelayanan yang efisien dan dapat diandalkan); fulfillment (pemenuhan); security/trust (keamanan/kepercayaan); site aesthetic 
(situs estetika); responsiveness/ contact (daya tanggap / kontak); easy to use (mudah digunakan).

Kualitas pelayanan jasa bank dari pendapat Lovelock (2011: 155); Fandy Tjiptono (2012: 170-172) dan Farnaz (2012: 444), maka dapat disintesakan dimensinya sebagai berikut: Berwujud (tangibles). Penampilan fasilitas fisik, peralatan, personil, dan materi komunikasi. Kehandalan (reliability). Kemampuan untuk melakukan pelayanan yang dijanjikan, dapat diandalkan dan akurat. Daya tanggap (responsiveness). Kesediaan untuk membantu pelanggan dan menyediakan prompt pelayanan. Jaminan (assurance). Kredibilitas, kepercayaan, kejujuran penyedia pelayanan. Empati (emphaty). Akses yang mudah didekati, komunikasi mendengarkan pelanggan dan menjaga agar mereka terinformasikan dalam bahasa yang bisa dimengerti; memahami pelanggan, membuat upaya untuk mengenali pelanggan dan kebutuhan mereka. Mudah digunakan (easy to use). Produk mudah digunakan dengan ketersediaan informasi di web, kemudian kemudahan dalam bertransaksi.

\section{METODE}

Jenis penelitian yang digunakan dalam penelitian ini adalah penelitian menggunakan pendekatan survey. Survey kepada nasabah Bank PD. Sarimadu yakni kepada nasabah sebanyak 100 orang sampel. Data dikumpulkan dengan menggunakan kuesioner.

Definisi Operasional Variabel Pengembangan Kualitas Layanan Bank PD. BPR Sarimadu adalah sebagai perbandingan mengenai apa yang diharapkan konsumen dengan apa yang didapat oleh konsumen, dengan indikator dikenal dengan lima dimensi sebagai berikut:

1) Pengembangan bukti fisik bank. Penampilan fasilitas fisik, peralatan, personil, dan materi komunikasi.

2) Pengembangan kehandalan. Kemampuan untuk melakukan pelayanan yang dijanjikan, dapat diandalkan dan akurat.
3) Pengembangan daya tanggap bank. Kesediaan untuk membantu pelanggan dan menyediakan prompt pelayanan.

4) Pengembangan jaminan nasabah. Kredibilitas, kepercayaan, kejujuran penyedia pelayanan.

5) Pengembangan empati kepada nasaah Akses yang mudah didekati, komunikasi mendengarkan pelanggan dan menjaga agar mereka terinformasikan dalam bahasa yang bisa dimengerti; memahami pelanggan, membuat upaya untuk mengenali pelanggan dan kebutuhan mereka.

6) Pengembangan produk mudah digunakan. Produk mudah digunakan dengan ketersediaan informasi di web, kemudian kemudahan dalam bertransaksi.

Data yang terkumpul dianalisis secara deskriptif, yakni dengan menggambarkan secara gamblang hasil penelitian yang berkaitan dengan pengembangan kualitas layanan perbankan.

\section{HASIL}

Kualitas pelayanan adalah sebagai perbandingan mengenai apa yang diharapkan konsumen dengan apa yang didapat oleh konsumen. Kualitas Pelayanan diukur oleh 18 indikator pertanyaan dengan 6 dimensi yaitu Berwujud, Kehandalan, Daya Tanggap, Jaminan, Empati dan Mudah Digunakan. Berikut ini adalah rekapitulasi hasil tanggapan responden dari 18 indikator pertanyaan yang diajukan untuk mengukur Kualitas Pelayanan.

Apabila dilihat dari seluruh dimensi, maka dapat diketahui kualitas pelayanan BPR di Propinsi Riau dengan skor sebesar 3,1230 dengan standar deviasi 0,9920 masuk dalam kategori cukup baik menuju baik, dari 18 indikator penelitian dapat diketahui bahwa terdapat sebanyak dua indikator tertinggi adalah ketanggapan petugas dalam menghadapi keluhan nasabah BPR dan ketanggapan petugas memberikan solusi pada kredit nasabah BPR. Untuk lebih jelasnya dapat dilihat 
pada tabel berikut ini:

Tabel 1: Pengembangan Kualitas Layanan pada Bank PD BPR Sarimadu Bangkinang

\begin{tabular}{|l|c|l|}
\hline $\begin{array}{l}\text { Indikator pengembangan } \\
\text { kualitas layanan }\end{array}$ & Rata rata & Kategori \\
\hline $\begin{array}{l}\text { Pengembangan bukti fisik } \\
\text { bank }\end{array}$ & 3,0755 & Baik \\
\hline Pengembangan kehandalan & 3,5225 & Baik \\
\hline $\begin{array}{l}\text { Pengembangan daya tanggap } \\
\text { bank }\end{array}$ & 3,3503 & Baik \\
\hline $\begin{array}{l}\text { Pengembangan jaminan } \\
\text { kepada nasabah empati }\end{array}$ & 2,9406 & Cukup \\
\hline $\begin{array}{l}\text { Pengembangan } \\
\text { kepada nasaah }\end{array}$ & 2,9092 & Cukup \\
\hline $\begin{array}{l}\text { Pengembangan produk yang } \\
\text { mudah digunakan. }\end{array}$ & 3,1230 & Baik \\
\hline \begin{tabular}{l} 
Rata-Rata \\
\hline
\end{tabular}
\end{tabular}

Sumber: Data Olahan, 2018

Sedangkan dua indikator terendah adalah kemudahan mendapatkan informasi tentang kredit melalui website BPR dan memberikan konsultasi kepada nasabah BPR.

\section{PEMBAHASAN}

Masih kurangnya indikator dalam kualitas pelayanan hal ini dapat disebabkan dari dimensi Pengembangan bukti fisik bank dengan 3 item pertanyaan dinyatakan cukup baik dengan skor 3.0755, hal ini mengindikasikan bahwa perusahaan selalu dituntut untuk memberikan pelayanan secara nyata dan selalu berupaya mewujudkannya sehingga dapat memberikan pelayanan yang lebih baik kepada nasabah. Nilai yang paling rendah dari dimensi ini adalah pada pertanyaan "Kelengkapan fasilitas ATM dalam layanan transaksi", hal ini memperlihatkan bahwa BPR se Propinsi Riau belum memadai dalam memberikan kelengkapan fasilitas ATM dalam layanan transaksi nasabah.

Pada item, kesediaan bangunan kantor BPR dalam melayani nasabahnya dengan skor sebesar 3.5242 masuk dalam kategori baik, ini menunjukkan bangunan yang dimiliki oleh BPR tersebar dan juga memiliki bangunan yang representative dan dekat dengan nasabah. BPR menggunakan bangunan seperti ruko dan rumah dimana nasabah berada dan ini memberikan kemudahan kepada nasabah dalam mendapatkan pelayanan untuk bertransaksi dengan BPR. Nasabah dapat menarik dananya dan juga dapat membayar cicilannya dengan mudah apabila ada bangunan atau gedung sebagai kantor pelayanan kepada nasabahnya. Selain itu juga, sebagian BPR yang ada sudah memiliki bangunannya sendiri dan memiliki kantor kas yang dapat memberikan pelayanan kepada nasabahnya dalam kondisi yang diinginkan.

Pada item, kelengkapan fasilitas ATM dalam layanan transaksi dalam melayani nasabahnya dengan skor sebesar 2.8041 masuk dalam kategori cukup, memang dirasakan ATM belum tersedia dalam BPR, hal ini karena sistem yang diterapkan kepada BPR masih belum sempurna. Hal ini juga disebabkan karena pangsa pasar yang dimiliki oleh BPR merupakan masyarakat yang terkadang tidak membutuhkannya sehingga pihak BPR masih mempertimbangkan masalah untung rugi penggunaan ATM. Selain itu juga masalah keberadaan BPR yang jauh dari fasilitas jaringan komunikasi seperti internet, sehingga tidak memungkinkan bagi BPR dalam menyediakan fasilitas pelayanan ATM. Kemudian ATM juga membutuhkan sistem yang lebih sempurna dalam pelayanannya.

Pada item, penampilan petugas BPR dalam melayani nasabahnya dengan skor sebesar 2.8982 masuk dalam kategori baik, memang dirasakan BPR memiliki penampilan sederhana dan juga bangunan serta penampilan petugas dalam memberikan pelayanan kepada nasabah lebih humanis, karena nasabah BPR kebanyakan adalah mereka pada pedagang kecil dan mereka yang berjualan dipasar dan pedagang kaki lima, sehingga petugas selalu menyesuaikan diri dengan kondisi nasabah yang mereka miliki. Hal ini dimaksudkan agar nasabah merasa senang mendapatkan pelayanan langsung dari para 
petugas dalam memberikan pelayanan kepada mereka dan bankan penampilan petugas lebih kurang pedagang di lapangan.

Dari uraian di atas, maka dapat dikatakan bahwa wujud pelayanan yang diberikan BPR kepada nasabahnya seperti dalam hal kesediaan kantor pelayanan BPR dan juga kelengkapan fasilitas serta penampilanp petugas dalam melayani kesemuanya tersebut sudah cukup baik dan yang terbaik adalah pada masalah kesediaan bangunan memang sudah merata mencapai daerah-daerah terpencil. Sedangkan yang terendah menurut tanggapan responden adalah kelengkapan ATM dalam memberikan pelayanan transaksi kepada nasabahnya.

$$
\text { Kemudian dari dimensi }
$$

Pengembangan jaminan kepada nasabah dengan 3 item pertanyaan dengan skor yang diperoleh sebesar 2,9406, hal ini mengindikasikan bahwa perusahaan selalu dituntut untuk memberikan jaminan secara benar dan selalu berupaya mewujudkannya sehingga dapat meningkatkan kepercayaan nasabah. Nilai yang paling rendah dari dimensi ini adalah pada pertanyaan "Jaminan keamanan dokumen nasabah BPR", hal ini memperlihatkan bahwa BPR se Propinsi Riau belum memadai dalam memberikan jaminan keamanan dokumen nasabah.

Dari item mengenai jaminan pencairan kredit sesuai dengan kebutuhan waktu mendapatkan skor jawaban responden sebesar 3.5496 masuk dalam kategori baik, ini menunjukkan bahwa bahwa pada saat calon nasabah membutuhkan senilai dana untuk dipinjam selalu dari pihak BPR mampu menyediakan dana tersebut dan hal ini menjadi sebuah jaminan pada BPR untuk dapat memberikan pelayanan dengan jumlah dana yang dibutuhkan nasabahnya. Hal ini terutama berlaku kepada nasabah yang sudah berulang kali menjadi nasabah kredit BPR dan mereka selalu menjadi prioritas dalam memenuhi kebutuhan dana dari nasabah. Namun biasanya yang calon nasabah baru, mereka tetap mendapatkan perhatian dan harus menambah jaminan jika dinilai kurang memenuhi jaminan yang diagunkan.
Kemudian dari item mengenai jaminan asuransi nasabah BPR mendapatkan skor jawaban responden sebesar 2.6514 masuk dalam kategori cukup, ini menunjukkan bahwa BPR selalu memberikan jaminan asuransi kepada nasabah apabila terjadi sesuatu hal yang tidak diingin I seperti nasabah meninggal, maka ahli waris tidak perlu melanjutkan angsurannya lagi dan semuanya sudah diasuransikan oleh pihak BPR. Namun demikian, tidak semua BPR menerapkan hal tersebut, karena asuransi yang dikenakan kepada nasabah akan menambah beban nasabah dalam membayar angsuran dan terkadang pihak bank tidak menyediakan jasa asuransi kepada nasabah. Kemudian juga karena sebagian besar dari nasabah memiliki pinjaman jangka pendek, sehingga asuransi dinilai kadang layak diberikan dan kadang tidak layak diberikan kepada nasabahnya. Untuk nasabah yang memiliki pinjaman dengan jangka waktu lebih dari 3 tahun maka mereka diasuransikan oleh pihak bank.

Berkaitan dengan item mengenai jaminan keamanan dokumen nasabah BPR mendapatkan skor jawaban responden sebesar 2.6209 masuk dalam kategori cukup, ini menunjukkan bahwa BPR memberikan jaminan dokumen dan jaminan dokumen agunan yang diberikan nasbaha kepada BPR akan dijaminkan dan pihak notaris yang menyaksikan perjanjian antara bank dengan nasabahnya. Hal ini dilakukan dalam rangka memberikan rasa aman kepada nasabah dalam memberikan agunan pinjaman kepada BPR. Memang terkadang ada kendala dengan kondisi bangunan yang ada untuk kantor BPR, tidak memungkinkan berkas agunan disimpan di dalamnya, maka dari BPR menyimpannya di kantor pusat. Dan hal ini menyebabkan pengembalian jaminan pada saat sudah dilunasi pinjaman dari BPR juga mengalami keterlambatan karena harus diambil dari tempat penyimpanan dan terkadang memakan waktu sampai 4 hari kerja. Persoalan lainnya berkaitan dengan masalah jaminan surat tanah, terkadang 
pihak BPR sudah membuat surat badan pertanahan dan juga mengenai masalah ini menyebabkan keterlambatan untuk mengembalikan status surat tanah dalam tanggungan tersebut dikembalikan kepada milik nasabah.

Berdasarkan dari uraian mengenai jaminan yang diberikan pihak BPR kepada nasabahnya dalam kategori cukup baik dan hal ini yang paling tinggi adalah pada item jaminan pencairan kredit sesuai dengan kebutuhan nasabah dan yang paling rendah adalah pada jaminan keamanan agunan yang diberikan kepada BPR dan ini menjadi persoalan yang perlu mendapatkan solusi dan nasabah sebagian ada yang kecewa dengan jaminan ini.

\section{Dimensi Pengembangan empati}

kepada nasaah dengan 3 item pertanyaan dengan skor yang diperoleh sebesar 2.9398, hal ini mengindikasikan bahwa perusahaan selalu dituntut untuk memperlakukan nasabah secara baik dan selalu berupaya mencerminkan sikap yang ramah terhadap semua nasabah. Nilai yang paling rendah dari dimensi ini adalah pada pertanyaan "Memberikan konsultasi kepada nasabah BPR", hal ini memperlihatkan bahwa BPR se Propinsi Riau belum memadai dalam memberikan konsultasi kepada nasabah atas produk layanan yang ada di BPR.

Dilihat dari item memberikan perhatian kepada nasabah BPR dengan skor yang diperoleh sebesar 2.8270 masuk dalam kategori cukup baik dan ini menunjukkan bahwa BPR selalu memberikan perhatian kepada nasabah, perhatian ini lebih kepada bagaimana hal-hal yang menyentuh perasaan nasabah menjadi perhatian dari BPR, seperti ikut hadir dalam acara kenduri dan acara pesta yang diadakan oleh nasabah dan BPR mendapatkan undangan dan bahkan BPR selalu memberikan karangan bunga kepada nasabah yang mengadakan acara. Memang dirasakan kedekatan BPR dengan masyarakat sebagai nasabahnya dan ini menjadi sebuah nilai lebih bagi para nasabahnya. Selain itu juga perhatian pada masalah meningatkan waktu jatuh tempo pembayaran angsuran nasabah juga selalu diingatkan oleh petugas
BPR dan memang terkadang terkesan nyinyir oleh nasabah, namun hal ini membuat nasabah mendapatkan perhatian agar tidak menunggak angsuran dan tidak dikenakan denda.

Kemudian dilihat dari item memberikan konsultasi kepada nasabah BPR dengan skor yang diperoleh sebesar 2.5725 masuk dalam kategori cukup baik dan ini menunjukkan bahwa dalam hal pengajuan kredit dan juga pembayaran angsuran kredit selalu petugas BPR menjadi konsultan bagi nasabah, mereka selalu mendapatkan telpon dan juga nasabah bertanya secara langsung menemui petugas BPR untuk mendapatkan solusi dari masalah yang dihadapinya. Hal ini menjadi sebuah harapan dari nasabah dalam rangka mendapatkan perhatian dari masalah yang dihadapi.

Juga dilihat dari item memberikan pesan singkat kepentingan nasabah BPR dengan skor yang diperoleh sebesar 3.4198 masuk dalam kategori baik dan ini menunjukkan bahwa petugas BPR selalu memberikan pesan singkat dalam bentuk SMS kepada nasabah dan hal ini dilakukan dalam rangka mengingkatkan kepada nasabah akan hal-hal penting dan hari-hari bermakna kepada nasabah, seperti ucapan selamat ulang tahun, kemudian selamat hari raya dan juga berkenaan dengan masalah kemalangan dengan turut berbela sungkawa kepada keluarga yang mengalami kemalangan. Usaha empati ini dilakukan dalam rangka membangun kebersamaan antara keluarga besar BPR dalam rangka membuat nasabah tidak merasa sendirian dan tetap mendapatkan perhatian dari berbagai kalangan seperti juga dari pihak BPR dalam kondisi senang maupun susah dari nasabah.

Dari uraian mengenai empati dari BPR kepada nasabahnya memang dirasakan sudah cukup baik dan yang paling baik adalah pada item menyampaikan pesan singkat kepada nasabah dalam berbagai keadaan nasabah dalam mewujudkan rasa empati kepada nasabah. Kemudian yang paling rendah adalah masalah memberikan 
konsultasi kepada nasabah, karena terkadang dengan jumlah nasabah yang dilayani tidak sebanding dengan petugas yang melayani, sehingga terkadang melayani nasabah dengan terburu-buru hal ini terkadang membuat nasabah sedikit kecewa dari pelayanan yang diberikan dalam hal konsultasi masalah nasabah.

Terakhir

$$
\text { pada }
$$

dimensi

Pengembangan produk yang mudah digunakan. dengan 3 item pertanyaan dengan skor yang diperoleh sebesar 2.9092, hal ini mengindikasikan bahwa perusahaan selalu dituntut untuk memberikan layanan jasa yang memuaskan nasabah dan selalu berupaya meningkatkan layananya agar sesuai dengan kebutuhan nasabah. Nilai yang paling rendah dari dimensi ini adalah pada pertanyaan "Kemudahan mendapakan informasi tentang kredit melalui website BPR", hal ini memperlihatkan bahwa BPR se Propinsi Riau belum memadai dalam memberikan kemudahan mendapakan informasi tentang kredit melalui website BPR.

Dilihat dari item kemudahan membayar cicilan dengan menerima berapa adanya oleh petugas BPR dengan skor yang diperoleh sebesar 2.7786 masuk dalam kategori cukup baik dan ini berarti bahwa sebagian petugas BPR dalam memberikan pelayanan kepada nasabah dalam hal membayar angsuran, terkadang menerima berapa adanya uang yang dimiliki oleh nasabah dan terkadang tidak harus penuh sampai penuh angsurannya dan petugas menerima dalam misalnya baru $50 \%$. Usaha yang dilakukan petugas BPR ini adalah bentuk kemudahan yang diberikan kepada nasabah oleh petugas dan petugas selalu memperhatikan dan mengingatkan serta petugas juga mau menjemput angsuran yang memang nyata-nyata belum penuh angsuran yang ada. Kemudian kerjasa keras petugas dalam mengumpulkan angsuran menjadi sebuah bentuk kemudahan yang diberikan petugas kepada nasabah. Selain itu juga, petugas terkadang memberikan kemudahan menjemput aplikasi permohonan kredit yang persyaratannya masih ada di rumah dan ini juga perhatian dalam rangka usaha untuk tetap memberikan kemudahan kepada nasabah.

Kemudian dilihat dari item kemudahan mendapakan informasi tentang kredit melalui website BPR dengan skor yang diperoleh sebesar 2.5445 masuk dalam kategori cukup baik dan ini berarti bahwa BPR selama ini sudah menyediakan sumber informasi yang dapat diterima dan dibaca oleh nasabah, website disediakan dan indormasi yang ada sudah disediakan mengenai profil BPR dan juga segala macam bentuk informasi yang dibutuhkan nasabah dalam ranga mendapatkan informasi mengenai BPR. Namun masalah yang terjadi terkadang informasi yang ada dalam website tidak uptodate atau tidak terkini, sehingga terkadang nasabah tidak menggunakan informasi yang disediakan BPR tersebut. Masalah yang dihadapi BPR dalam rangka mengupdate informasi juga menjadi kendala yang dirasaan dan hal ini menjadikan perhatian dari BPR dalam rangka memberikan pelayanan yang optimal kepada nasabah.

Dilihat dari item kemudahan bertransaksi melalui seluruh kantor cabang/kas BPR dengan skor yang diperoleh sebesar 3.4046 masuk dalam kategori baik dan ini berarti bahwa BPR memberikan kemudahan untuk bertransaksi di seluruh kantor cabang dan kantor kas yang dimiliki BPR, hal ini karena mereka memiliki data yang sama yang dapat diakses oleh pihak bank. Kemudahan ini juga merupakan kebijakan dari BPR dalam rangka memberikan kemudahan untuk menjadikannya BPR lebih baik dalam memberikan pelayanan kepada nasabahnya. Berdasarkan uraian mengenai mudah digunakan dari BPR oleh nasabah dapat dikatakan sudah cukup baik dan dimana yang paling baik adalah berada pada dimensi kehandalan petugas dalam memberikan pelayanan, dimana sebagai nasabah bila membutuhkan pinjaman maka mereka selalu mendapatkannya. Kemudian dimensi yang paling rendah adalah pada mudah digunakan, dimana dengan 
keterbatasan fasilitas seperti ATM dan informasi pada website belum update menyebabkan jasa BPR tidak mudah digunakan dimana-mana.

Kemudian dari jawaban yang di atas rata-rata seperti pada dimensi Pengembangan kehandalan dengan 3 item pertanyaan dinyatakan baik dengan skor 3.5225 , hal ini mengindikasikan bahwa perusahaan selalu dituntut untuk memberikan pelayanan secara handal dan selalu berupaya mewujudkannya sehingga dapat memberikan pelayanan yang lebih baik kepada nasabah. Nilai yang paling rendah dari dimensi ini adalah pada pertanyaan "Kehandalan pencairan kredit tepat waktu", hal ini memperlihatkan bahwa BPR se Propinsi Riau belum memadai dalam memberikan kehandalan pencairan kredit secara tepat waktu.

Apabila dilihat dari item kehandalan petugas memberikan pelayanan angsuran dengan skor 3.5903 dengan kategori baik ini menunjukkan bahwa petugas BPR handal dalam memberikan layanan angsuran, dimana petugas siap memberikan pelayanan menjemput angsuran ke rumah nasabah, hal ini memang sudah dimaklumi keterbatasan waktu yang dirasakan oleh nasabah, yang mana mereka sebagian tidak ada waktu yang cukup untuk datang ke BPR dalam rangka membayar angsuran. Memang atasa dasar permintaan dari nasabah maka petugas siap memberikan pelayanan menjemput angsuran dan ini sudah menjadi kebijakan dari BPR itu sendiri dalam memberikan pelayanan ekstra kepada nasabah. Namun ada sebagian nasabah yang tidak ingin tagihannya dijemput karena dengan alasan mereka malu apabila diketahui masyarakat mereka memiliki hutang di bank, sehingga petugas tidak melakukan penjemputan terhadap cicilan nasabah dan ada nasabah yang memang membandel dalam membayar angsuran sehingga memang dilakukan penjemputan dan melihat langsung bagaimana kondisi nasabah dan dicari informasi apa alasan angsurannya masih belum dibayarkan. Hal ini selalu dilakukan petugas dalam rangka membuat layanan angsuran berjalan dengan baik.
Kemudian dilihat dari item kehandalan pencairan kredit tepat waktu dengan skor 3.5903 dengan kategori baik ini menunjukkan bahwa menurut respoden BPR sudah memberikan pelayanan pencairan kredit tepat waktu dan bahkan dalam hal pencairan kredit BPR lebih cepat dibandingkan dengan bank konvensional lainnya. Hal ini karena memang BPR mempunyai kebijakan bagaimana memahami kebutuhan nasabahnya dengan baik. Terkadang dari pihak BPR karena dinilai nasabah sudah memiliki kalayakan sebagai penerima kredit, maka berapa permintaan dari nasabah sudah langsung saja di setujui dan bahkan persyaratan bisa menyusul belakangan. Kondisi menjadi kelebihan dari BPR dalam memberikan pelayanan pencairan kredit kepada nasabahnya. Selain itu juga karena nasabahnya adalah orang-orang disekitar dimana BPR itu berada dan juga dengan bantuan petugas yang juga berasal dari daerah setempat mempermud BPR dalam mempertimbangkan kondisi nasabah yang ada.

Juga dapat dilihat dari item kehandalan proses kredit bagi nasabah BPR dengan skor 3.5903 dengan kategori baik ini menunjukkan bahwa dirasakan oleh responden bahwa BPR dalam menerapkan proses kredit sangat fleksibel, dimana dengan kebutuhan dana dari masyarakat yang menjadi calon nasabahnya mereka dengan lebih cepat dalam menyelesaikan proses kredit yang diberikan kepada calon nasabah dan bahkan bagi nasabah yang sudah berulang kali menjadi nasabah bahkan mereka ditawari untuk pinjaman yang lebih dan menjadi bagian dari keluarga besar BPR khususnya sebagai nasabah prima. Kelebihannya berkaitan dengan proses kredit kepada nasabah yang sudah menjadi nasabah prima adalah tinggal butuh berapa dana dan pihak bank akan langsung mencairkan sedagkan persyaratan dapat dilengkapi belakangan.

Dari dimensi kehandalan ini memang dirasakan sudah baik dimana kehandalan yang paling baik berada pada 
kehandalan petugas dalam memberikan pelayanan angsuran. Sedangkan kehandalan paling rendah adalah pada kehandalan dalam proses kredit bagi nasabah BPR, karena tidak semua nasabah mendapatkan perlakuan prima dari BPR.

Selanjutnya diikuti dengan dimensi Pengembangan daya tanggap bank dengan 3 item pertanyaan dinyatakan cukup baik dengan skor 3.3503, hal ini mengindikasikan bahwa perusahaan selalu dituntut untuk memberikan pelayanan secara tanggap dan selalu berupaya mewujudkannya oleh petugas bank sehingga dapat memberikan pelayanan yang lebih baik kepada nasabah. Nilai yang paling rendah dari dimensi ini adalah pada pertanyaan "Ketersediaan kotak saran pada kantor BPR", hal ini memperlihatkan bahwa BPR se Propinsi Riau belum memadai dalam menyediakan ketersediaan kotak saran pada kantor BPR.

Item tentang ketanggapan petugas dalam menghadapi keluhan nasabah BPR dengan skor 3.5674 masuk dalam kategori baik dan ini berarti bahwa BPR pada dasarnya sudah memberikan dengan baik ketanggapan petugas dalam menghadapi keluhan nasabah BPR, hal ini dapat ditunjukkan dari berbagai keluhan yang dirasakan nasabah seperti dalam keluhan untuk melengkapi berbagai persyaratan yang menjadi dasar diberikannya kredit, pihak BPR akan mencarikan persyaratan yang dimiliki oleh calon nasabah, sehingga calon nasabah tetap dapat menjadi nasabah dengan pertimbanyakan bankable daripada nasabah sudah mencakup kondisi yang aman. Selain itu juga, BPR dalam menanggapi keluhan layanan pembayaran angsuaran sudah memang tanggap mereka menyiapkan petugas yang siap menjemput dan memberikan pelayanan angsuran sampai dimana posisi nasabah. Juga masalah kantor pelayanan, BPR sudah menyediakan kantor pelayanan nasabah sampai dengan menyediakan kantor kas yang dekat dengan nasabah. Hal ini dilakukan dalam rangka membuat nasabah tetap setia kepada BPR. Namun ada juga keluhan nasabah yang belum terpenuhi, seperti penyediaan mesin
ATM, dimana pihak BPR sudah mempertimbangkannya namun kondisi fasilitas yang belum memungkinkan BPR sehingga akan berdampak kepada kesehatan BPR itu sendiri.

Kemudian dilihat dari Item tentang ketanggapan petugas memberikan solusi kepada kredit nasabah BPR dengan skor 3.5623 masuk dalam kategori baik dan ini berarti bahwa responden merasa sudah adanya ketanggapan petugas memberikan solusi kepada kredit nasabah BPR. Banyak usaha yang dilakukan BPR agar calon nasabah tetap dapat menjadi nasabah BPR. Misalnya untuk pelayanan kredit bakulan, pedagang yang sibuk dalam menjalankan dagangannya didatangi oleh petugas BPR untuk menawarkan produk bakulan dan diberikannya pinjaman langsung dimana pedagang berdagang, sehingga pedagang tidak harus ke kantor BPR untuk mendapatkan pinjaman dari BPR. Selain itu juga, petugas akan mendatangi kembali pedagang untuk masalah penyetoran pinjaman kepada BPR. Ini dilakukan oleh BPR dalam rangka memberikan kemudahan kepada calon nasabah untuk memberikan solusi dari masalah yang dihadapi nasabah dalam mendapatkan layanan BPR.

Juga pada Item tentang ketersediaan kotak saran pada kantor BPR dengan skor 2.9211.5674 masuk dalam kategori cukup baik dan ini berarti bahwa memang dirasakan kotak saran sebagian BPR belum tersedia dengan baik dan juga sebagian sudah ada di dalam website dan memang belum ada upaya BPR untuk menindaklanjuti saran-saran yang ada diberikan nasabah kepada BPR itu sendiri. Selain itu juga, memang dinilai nasabah yang ada pada dasarnya dapat menyampaikan sarannya langsung kepada petugas lapangan yang memberikan pelayanan dan hal ini selalu menjadi perhatian dari direksi dalam rangka menjawab berbagai persoalan yang dihadapi BPR dalam rangka menjadikan BPR lebih baik lagi ke depannya. Saran memang dari nasabah ada yang berkaitan dengan peningkatan pelayanan transaksi 
seperti mesin ATM dan juga saran mengenai bunga yang ditetapkan BPR, namun semua itu tetap menjadi pertimbangan oleh pihak BPR untuk bagaimana memberikan jawaban kepada nasabah dan juga mempertimbangkan kondisi yang ada di BPR itu sendiri.

Dari uraian mengenai dimensi daya tanggap memang sudah dinilai cukup baik oleh nasabah BPR, dimana hal yang paling tinggi dan mendapatkan perhatian berkaitan tentang menanggapi keluhan nasabah dan juga berkaitan dengan memberikan solusi dari keluahan yang ada. Sedangkan yang paling rendah adalah pada masalah kotak saran dalam upaya menampung saran dari nasabah dalam rangka memajukan BPR ke depannya.

Rekapitulasi hasil jawaban responden mengenai kualitas pelayanan memiliki ratarata 3,1230 dan standar deviasi 0,9220 dinyatakan termasuk kategori cukup baik, hal ini mengindikasikan bahwa BPR se Propinsi Riau, sangat bervariatif, dimana katagorinya dari kualitas pelayanan cukup baik menuju baik. Oleh karena itu masih perlu adanya upaya peningkatan kualitas pelayanan. Hal yang perlu mendapatkan perhatian paling serius pada kualitas pelayanan adalah terletak pada dimensi mudah digunakan maka perlu adanya kemudahan bertransaksi.

Kondisi variabel kualitas pelayanan yang masuk dalam kategori cukup baik ini lebih dikarenakan kurangnya kelengkapan fasilitas ATM dalam layanan transaksi, kemudian kurangnya menariknya penampilan petugas BPR dalam melayani nasabahnya, juga disebabkan kurang tersedianya kotak saran pada kantor BPR, kurangnya adanya jaminan asuransi nasabah BPR, kurangnya jaminan keamanan dokumen nasabah BPR, kurangnya diberikannya perhatian kepada nasabah BPR, kurang diberikannya konsultasi kepada nasabah BPR, kurangnya kemudahan membayar cicilan dengan menerima berapa adanya oleh petugas BPR dan kurangnya kemudahan mendapakan informasi tentang kredit melalui website BPR.

Apabila dikaitkan dengan profil responden lama meminjam, bahwa responden sudah sampai dengan 10 tahun sudah meminjam di BPR dan ini merupakan pelanggan yang loyal dan beberapa kali telah meminjam, oleh karenanya perlu mendapatkan pelayanan yang lebih baik lagi guna meningkatkan rasa percaya pada BPR.

\section{SIMPULAN}

Kesimpulan yang diambil dalam artikel ini adalah bahwa dalam rangka mengembangkan kualitas layanan perusahaan ini maka yang perlu dilakukan adalah melakukan pengembangan bukti fisik bank. Penampilan fasilitas fisik, peralatan, personil, dan materi komunikasi; pengembangan kehandalan. Kemampuan untuk melakukan pelayanan yang dijanjikan, dapat diandalkan dan akurat; pengembangan daya tanggap bank. Kesediaan untuk membantu pelanggan dan menyediakan prompt pelayanan; pengembangan jaminan nasabah. Kredibilitas, kepercayaan, kejujuran penyedia pelayanan; pengembangan empati kepada nasaah Akses yang mudah didekati, komunikasi mendengarkan pelanggan dan menjaga agar mereka terinformasikan dalam bahasa yang bisa dimengerti; memahami pelanggan, membuat upaya untuk mengenali pelanggan dan kebutuhan mereka dan pengembangan produk mudah digunakan. Produk mudah digunakan dengan ketersediaan informasi di web, kemudian kemudahan dalam bertransaksi.

\section{DAFTAR RUJUKAN}

Fandy Tjiptono, 2000, Manajemen Jasa, Penerbit Andi Yogyakarta

Gareth Jones and Mary Mathew, 2009, Organizational Theory, Design and Change, 5th Edition (Delhi : Dorling Kindersley, 2009)

Groonros Christian, 2006. Service Management and Marketing. A Moment of Truth. Singapore. Maxweel Mcmillan International. 
Kurt, David L and Kenneth Clow.2008. Service Marketing. Singapore. John Wiley \& Sons, Inc.: 24-30.

Kisworo, 2013, BPR Harus Jadi "Penjaga Rumah" Ekonomi Nasional, Infobank, Jakarta.

Kotler and Amstrong, 2010. Manajemen Pemasaran. Edisi 13 Jilid 2. Jakarta. Erlangga

Kusmayadi, Tatang. 2007. Pengaruh Relationship Quality Terhadap Loyalitas Nasabah Tabungan. Skripsi. STIE STAN Indonesia Mandiri.

Lovelock. C, 2010, Pemasaran Jasa. Erlangga, Jakarta

Lupiyoadi, Hamdani. 2006. Manajemen Pemasaran Jasa, Edisi Kedua. Penerbit Salemba Empat. Jakarta.

Othman, A \& L Owen, 2001. Adopting And Measure Customer Service Quality (SQ) in Islamic Banks: A Case Study in Kuwait Finance House, International Journal of islamic Financial service Vol. 3 No.1

BPS, 2016, Riau dalam Angka, Pekanbaru.

Rust, Roland T. 2004. Customer Satisfaction, Customer Retention, and Market Share. Journal of Retailing.

Santoso Singgih, 2002 Statistik Parametrik, Cetakan Ketiga, PT Gramedia Pustaka. Utama, Jakarta

Sugiyono. 2016. Metode Penelitian Kuantitatif, Kualitatif dan R\&D. Bandung: PT Alfabet.

Tandjung, J.W., 2004, Marketing Management: Pendekatan Pada
Nilai-nila. Pelanggan, Edisi Kedua, Jakarta.

Tjiptono dan GregoriusChandra, 2005, Manajemen Kualitas Jasa,. Yogyakarta. ANDI. , 2014, Pemasaran Jasa, Andi Offset, Yogyakarta.

Santoso, S. 2012. Riset Pemasaran Riset dan Aplikasi dengan SPSS. PT. Elex Media Komputindo. Jakarta

Undang-Undang Dasar 1945 pasal 33 tentang perekonomian

Undang-Undang Nomor 21 Tahun 2011 tentang Otoritas Jasa Keuangan (Lembaran Negara Republik Indonesia Tahun 2011 Nomor 111, Tambahan Lembaran Negara Republik Indonesia Nomor 5253)

Peraturan Otoritas Jasa Keuangan Nomor 20/POJK.03/2014 tentang Bank Perkreditan Rakyat

Permendagri No. 94 Tahun 2007, tentang Pengelolaan Bank Perkreditan Rakyat Milik Pemerintah Daerah. 